Georgia State University

ScholarWorks @ Georgia State University

Middle and Secondary Education Faculty

Publications

Department of Middle and Secondary Education

2010

\title{
Overwrought Copyright: Why Copyright Law from the Analog Age does not Work in the Digital Age's Society and Classroom
}

\author{
Ewa McGrail \\ Georgia State University \\ J. Patrick McGrail \\ Jacksonville State University
}

Follow this and additional works at: https://scholarworks.gsu.edu/mse_facpub

Part of the Curriculum and Instruction Commons, and the Junior High, Intermediate, Middle School Education and Teaching Commons

\section{Recommended Citation}

McGrail, Ewa and McGrail, J. Patrick, "Overwrought Copyright: Why Copyright Law from the Analog Age does not Work in the Digital Age's Society and Classroom" (2010). Middle and Secondary Education Faculty Publications. 101.

https://scholarworks.gsu.edu/mse_facpub/101

This Article is brought to you for free and open access by the Department of Middle and Secondary Education at ScholarWorks @ Georgia State University. It has been accepted for inclusion in Middle and Secondary Education Faculty Publications by an authorized administrator of ScholarWorks @ Georgia State University. For more information, please contact scholarworks@gsu.edu. 
Overwrought Copyright: Why Copyright Law from the Analog Age does not Work in the Digital Age's Society and Classroom

\section{McGrail, J. Patrick}

Assistant Professor of Communication

Jacksonville State University

Dept. of Communication

College of Education and Professional Studies

700 Pelham Road North

Jacksonville, AL 36265

(256) 782-5300 (office voice)

E-mail: jmcgrail@jsu.edu

\section{McGrail, Ewa}

Assistant Professor of Language and Literacy

Georgia State University

College of Education

30 Pryor St.,

Atlanta, GA 30303

404-413-8389 (office voice)

404- 413-8063 (fax)

E-mail: emcgrail@gsu.edu

\begin{abstract}
In this article, the authors argue that copyright law, conceived of in an "analog" age, yet made stricter in our present Digital Age, actively stifles creativity among today's student creators, both by its bias toward content owners and its legal vagueness. They also illustrate that copyright law is too stringent in protecting intellectual content, because physical and virtual objects are not the same thing. They conclude with a call to revise copyright for new media content that meets the needs of both content creators and pre-existing media content owners, and that, most importantly, benefits the education of the creative and innovative mind in today's mediacentric classrooms.
\end{abstract}

Keywords: copyright, remixing, analog, digital, technology, content-creators, education, students; media arts, language arts 
Overwrought Copyright: Why Copyright Law from the Analog Age does not Work in the Digital Age's Society and Classroom

Copyright, in one form or another, has provided protection in the common law to authors and publishers, and has had some statutory presence in Western Europe and Great Britain for several centuries. Copyright's first comprehensive statutory enactment that specifically benefitted authors was England's Statute of Anne, enacted 1710 (as cited in The Avalon Project n.d.), which superseded all previous common laws and agreements, such as the Stationer's Act of 1557 (as cited in Mitrano 2007), that had vested rights of reproduction with printers, rather than authors.

In the United States, where pamphleteering and newslettering were likewise prominent, the founders of the Constitution held similarly concordant views on the rights of authorship, and enshrined these rights in the first article of the U.S. Constitution (1789). At the time of the constitution's framing, copyright covered books, graphical material, written music, manuscripts, paintings, architecture (in the form of plans) and sculpture. Today, the regulating statute of copyright, Title 17, Chapter 1, Section 102 of the U.S. Code (1976), as amended, touches nearly all creative expression in the plastic, literary and performing arts. The Copyright Act covers also software, in addition to the protections it receives through patent law. The scope of the Act greatly benefits authors, requiring only that their creative work be fixed in a "tangible medium of expression" such as a tape, disc, or a piece of paper (Title 17, Circular 92, Chapter 1, Section 101). Although everyday people make a distinction in their own lives between literature and humdrum emails, such latter expressions often have protection under copyright law.

The most important provisions of the Copyright Act of 1976 however, were developed before the advent of the digital revolution. Therefore, many hitherto unforeseen legal, ethical and social problems have emerged, because the relationship between an original work and an analog copy of it differs in important ways from that between an original and a digital copy of that work, yet legislators have been slow in amending the scope and functionality of copyright law to embrace these developments.

In this article, we explain the essence of copyright law and discuss how Digital Age developments continue to challenge the "analog law" that is copyright. We illustrate that copyright law is too stringent in protecting intellectual content, because physical and virtual objects are not the same thing. We conclude with a call to revise copyright for new media content that meets the needs of both content creators and pre-existing media content owners, and that most importantly benefits the education of the creative and innovative mind in today's mediacentric classrooms.

The Analog Age and Copyright

From a commercial standpoint, original works in the Analog Age had traditionally stood in stark relief from their copies. Authors and composers, for example, hand-created prose, poetry, music and other intellectual material on paper. If the work were a manuscript, its final form as a book bore little resemblance physically to the material it was derived from. The book represented a fixed and durable consumer product. Its material was encapsulated in an aesthetically pleasing form, consisting of illustrations and printed fonts that made indelible the material within. In essence, the book reified for the public the ephemeral quality of the original. The book was a kind of stamp of approval from a presumedly authoritative source - the 
publisher. The publisher was asserting that a given work was worthy of its commercial, and thus the reader's intellectual, attention.

In the case of music in the Analog Age, a composer would frequently write music in traditional notation, in anticipation of it being performed and having that performance captured in a "tangible medium of expression" (U.S. Constitution 1789, Title 17, Circular 92, Chapter 1, Section 101). At first that medium was a cylinder, and then various forms of disc records and then finally, analog audiotape. At the time of the 1976 Copyright Act, music was distributed on a vinyl LP (long-playing record), in a manner that, in a similarly physical way, prominently displayed the faith of a disseminator (in this case, the record company) in the creativity of the composer (Lee 1995).

Of course, piracy and illicit copying occurred in the pre-digital age (Gordon and Watt 2003), but they were kept in check by the nature of analog reproduction and recording. Although it was possible to make unauthorized copies of a book, the book's physical existence meant that it would usually be recognizable as an imitation, and could be offered as prima facie evidence of an illicit attempt to publish. Moreover, the long legal standing of an author's "copy-right" had by the time of the U.S. Constitution acquired respectability; Immanuel Kant (1785) railed against unauthorized books, carefully laying out why the intellectual property of authors had to be held sacrosanct in an essay, "Of the Injustice of Counterfeiting Books."

In the realm of audio, until the Digital Age, all copies one might make of a given analog audio recording were audibly inferior to the original (Gizelt 1997). Since pirates rarely had access to the original, they often attempted to make copies of copies, which were easy to identify by authorities and commercial interests. Hence, piracy was not the problem it is today (Kennedy, 2008). It is thus arguable that in the Analog Age, analog copyright law served creators, educators, publishers and end users in a balanced and measured way.

Computers and the Digital Age

The growth of computers and the Internet in the Digital Age has forever altered the balance between creators and consumers of copyrighted work. In part, this is because the digital revolution has altered the very act of copying and the very definition of such concepts as "original" and "copy".

The first stage of the Digital revolution was the Computer Revolution. Computers had actually been around in one form or another, depending on the definition, since Charles Babbage's Analytical Engine in the 1840s (Lee 1994). First planned in drawings, and then laboriously constructed over decades, this machine could perform complex calculations. However, it was not a "digital" computer, because it used mechanical contrivances to effect these calculations. Digital computers use a binary system of 1s and 0s which correspond to an "on-off" scheme, respectively, and permit calculation and memory by the presence or absence of an electrical charge (Kempf 1961). Once an outside object, e.g. musical or textual data, has been sampled by a computing device of any kind, and converted into binary code, this code can be stored in memory or transmitted, usually without error, and thus without loss of fidelity.

The first binary computer was probably the Z3, created by Konrad Zuse from 1939-1941 (Desmonde and Berkling 1966; Rojas 1999). By the 1960s, computers were fairly commonplace, but at large corporations only; their sheer size kept them impractical for home applications (Cordata 1996). 
Computing would always have been important in scientific and business applications, but Steve Jobs and Steve Wozniak believed that individuals should have access to computing power in the home, both for work and recreation (Inventor of the Week 2007). They created the Apple computer in a garage on April Fool's Day, 1976. The Apple I was followed by the Apple II, and this series of computers was successful and long-lived, in part because a wide variety of software was available for this computer, and thus encompassed a range of activities to engage the consumer (Weyhrich 2001). In 1984, Apple introduced the Macintosh, and it can be said that this model helped make computers truly popular for home use (Reimer 2005). The key was the use of a Graphical User Interface (GUI), which made computing more visual and with a gentler learning curve for the novice user (Reimer, 2005). In a sense, GUIs contributed to the entertainment value of the computer. This value ensured its continuation as a mass-produced consumer product (Tuck 2001). Later, visuality and sound production would reinforce the personal computer's popularity in the marketplace.

Personal computers trended up in use in the 1980s, and became a mass-produced appliance for the home by the early 1990s (Timeline of Computer History n.d.). By the late 1980s, computer-assisted music compositions became possible, often using Musical Instrument Digital Interface (MIDI). It was not long before many computers were being used by home enthusiasts for the production of music and the manipulation of visual art. This was the dawn of the second, or true, Digital Age.

The Digital Age and Copyright

In the first stage of the Digital Age, the early 1990s, it became possible for consumers to make perfect copies of compact discs. However, record companies successfully lobbied for, and passed, the Audio Home Recording Act of 1992 (AHRA), Title 17, Chapter 10 of the U.S. Code, which permitted one digital copy of the original, but not a digital copy of that copy (Stapleton and Walker 2002). However, because computer disc drives were specifically exempted from the Act's requirements, technological advancement soon overwhelmed the usefulness of the Act. Within five years, it became possible for most computers to be able to copy any given audio disc.

The second stage of the computer revolution in the Digital Age was the rise of the Internet and the concurrent development of the MP3, the latter of which permitted a tenfold reduction in the size of a digital music file without much loss in audible quality. This meant that making perfect, or at least high quality, copies of digital media was married to the ability to transmit these copies across cyberspace (Langenderfer and Cook 2001). In June, 1999, 19-yearold college student Shawn Fanning (whose nickname was "the Napster") created a file sharing system named after himself, and a "perfect storm" of digital copying, streaming, and transmissibility was created. At its height, in February of 2001, roughly 50 million users shared music files over Napster (Talab 2002).

As we look back, we may find it surprising that Fanning and his supporters could ever have believed that what they did was legal, let alone ethical. According to Fanning's attorneys, "Napster users are not direct copyright infringers, because they are either covered by the immunity granted by the Audio Home Recording Act (AHRA 1992) and/or their use is a fair use; and even if there is direct copyright infringement, the elements of contributory copyright infringement and vicarious liability have not been shown" (UCLA Online Institute for Cyberspace Law and Policy 2001). 
However, at the time, some scholars and lawyers (e.g. Hurwitz, 2005) argued that the 1976 Copyright Act had not prepared anyone for the eventuality of instantaneous transmission. Fanning and his attorneys pointed out that it was far from clear that Napster had injured any copyright holder's commercial interests; rather, in the case of some artists, it may have resulted in greater subsequent record sales (Boorstin 2004). Nevertheless, the Ninth Circuit Court disagreed, and ordered Napster to cease its practices permitting dissemination of materials represented by the plaintiff, the RIAA. The district court for Northern California finally ordered Napster shut in July of 2001(Langenderfer and Cook 2001).

At first blush, the legal decision to close Napster does not necessarily give one pause. In a capitalist system, the wholesale sharing of huge quantities of intellectual property without compensation could never have been sustained indefinitely. Nevertheless, the digital revolution has transformed our understanding of copyright and what is meant by the term "copy." To understand this, we must revisit how two groups, the music industry and the music buying public, initially viewed digital music such as CDs. Bandwidth considerations and the much later digitization of visual media have meant that the Digital Age began with audio material and still images. However, we believe many of the same processes and concerns will prevail in the near future for digital visual media.

\section{Marketing Digital Products and Consumer Attitudes}

For many years, music companies had been traditional businesses, selling defined units of creative output - first analog records and cassettes, and finally, compact discs. Although CDs have always been a digital medium, initially, the word "digital" was just a tool record companies used to tout the superiority of the CD product (e.g. Blake 1982), a more compact alternative to the vinyl LP. At the time they were introduced, in 1982, it was impossible for the consumer to copy them (except via analog means), so mass copying was not perceived as much of a commercial problem (Stapleton and Walker 2002). People visited brick-and-mortar stores to purchase physical CDs, as with any other consumer product. Therefore, when growing Internet bandwidth, the rise of Napster and faster computers with bigger hard drives coalesced in the late 1990s to weaken the business and cultural model of traditional music retailing, record companies were caught off guard.

For the music buying public, on the other hand, another development of the Computer and Digital Age had begun to modify consumer attitudes and behavior. In the years prior to the development of the lingua franca of the Windows operating system, the software market had been dominated by specific business applications for mainframes. The market for consumer software was not considered particularly lucrative, and such software could often be acquired free of charge (EPSS Designer's Gallery - Consumer Software n.d.). Moreover, the "hacker" culture that had sprung up around software-designing groups at the Massachusetts Institute of Technology (MIT), the University of California at Berkeley, and Carnegie Mellon University specifically eschewed privatization and embraced "open source" and free software (Raymond 2000), where many programmers strove, without seeking profit, to improve a piece of software and permit it do more than that for which it was originally intended (Levy 2001).

The spectacular success of Windows in the 1990s changed all that. Via the Windows environment, Microsoft and supporting companies saw that consumer software might actually become profitable. However, they had to find a way to introduce their products to an untested market. They began to regularly offer trialware, freeware and shareware versions of programs. 
At the same time, this reinforced an attitude among many, especially in the freeware/hacker community, that actually paying for software was imprudent (Levy 2001). Once freeware advocates acquired one of these purportedly free pieces of software, they saw no ethical impediment in sharing it with their friends, and eventually, their online acquaintances (cf. websites Zeropaid.com, thepiratebay.org).

The attitudes that prevailed with software seemed to persist later on with regard to the sharing of music. Music sharing began in earnest with MP3s, but the explosion of such filesharing began when universities added high-bandwidth connections, such as T1 servers in the mid- to late 1990s (Nyiri 2004). Students who had permission to use capacious bandwidth frequently did so with the purpose of trading Mp3s with their friends, since the small file size permitted quick transmission over such services as Napster in a reasonable period of time, and did not occupy a great deal of space in the relatively meager hard drives of the last decade.

Thus, a combination of preexisting attitudes that originated in the software development community, the availability of high bandwidth connections, and a file format that was particularly conducive to transmission, led to an unsustainable explosion in the proliferation of digital copies of intellectual property.

Record companies at first reacted slowly to the developments. They were apparently unsure if the massive copying was helping or hurting record sales (e.g. Oberholzer and Strumpf, 2004; Peitz and Waelbroeck 2003) and many artists were, if anything, somewhat supportive of the practice, with the highly publicized exception of the heavy metal band Metallica (Strauss 2003). Hence, the public, especially the youthful music-buying public, did not initially associate file-sharing activity with unlawful activity (van Hooff 2007).

More recently, the growth of so-called Web 2.0 technologies, that stress social networking online, have fostered an explosion of the sharing of photographs, movies, television shows and other artifacts by young people, sometimes wittily altered from their original form and context (van Hooff 2007). At the very same time, two U.S. laws of the late 1990s - the Sonny Bono Copyright Extension Act (1998) and the Digital Millennium Copyright Act (1998) were written with provisions that both enhanced protections for copyright holders and were destined to collide with the legal and ethical practices of young digital media users.

Was this collision unforeseen? For some, it may have been the result of mere ignorance. A recent study by Aufderheide, Jaszi and Brown (2007) found that the subjects of their study, collegiate online video content creators, were "universally under-informed and misinformed about the [copyright] law" (1). Others associated this collision with a decrease in respect of intellectual property in web-based environments, as reported in a study entitled "Information Behaviour of the Researcher of the Future" (2008). Still others doubtless believe that the Napster decision and similar court findings have been wrongly decided, and are tapping a reservoir of ill feeling against the record companies (cf. Boehlert, 2000). For student creators who have grown up in the Digital Age, the "analog" copyright law may seem like a relic. Are they in part correct? How exactly do digital media differ from their analog counterparts?

\section{The Digital Media Taxonomy}

Samuelson (1991) has argued for a "taxonomy" of digital media, or a list of characteristics that irrevocably distinguish them from their earlier, analog counterparts. They consist of: 
1. The ease of [exact, or near-exact] replication;

2. The ease of transmission and [resultantly,] multiple use;

3. The plasticity of digital media [and the ease of digital manipulation, both overt and covert];

4. The [growing] equivalence of works in digital form. [By equivalency, Samuelson meant that copyrighted works, when digitized, are equivalent to one another in an essential way, because they share the same medium, both broadly in binarity (the 1's and 0 's of computer code) and more specifically, in their format (Word file, .wav, .mp3, etc.)];

5. The compactness of works in digital form;

6. Nonlinearity. [Distinctive marking characteristics in files permit searching and linking techniques for finding content in large quantities of digital media, without viewing all of the files].

To the above six characteristics, Lucchi $(2006,13)$ adds "intangibility". Digital copies have, in a sense, no one-to-one correspondence to physical reality. The copy "lies" in code on a chip, a piece of magnetic medium, or optically on a disc. Unlike books, digital media copies do not look or feel different, nor are heavier or lighter than digital media that contain longer, shorter, or even vastly different kinds of works. Moreover, the compact records created by digital media require a user interface to be decoded and viewed or listened to. Earlier, analog works consisted of content that was both directly apprehended in, yet could not be as easily extracted from, the medium in which it lay.

But it is copying that really distinguishes the digital from the analog. Initially, digital copying was used to make digital copies of analog media. In this situation, the digital copy would differ from the original in small ways, but every copy was precisely similar to every other copy. The "generational loss" (Nakano and Nakamura 1997) that earlier analog copying had entailed had given way to a scenario in which a first copy was nearly identical to the original, and precisely identical to other copies made at the same time. But a second reality also reared its head: copies of copies were exactly similar to the original copies. This meant that the concept of an "original," from which other "copies" are derived, had begun to lose its meaning. In the Digital Age, people may never know where the "original" of their copy is located. This has had the unintended consequence of media becoming problematic to give, sell or lend, without running afoul of copyright laws, because a renderer nearly always retains a copy of the content rendered to someone else (Oberholzer and Strumpf 2004).

The "give, sell, or lend" issue mentioned above is itself the subject of thorny legal questions. Do we actually "purchase" software? Is software sold or merely licensed? Many software manufacturers assert the latter definition (Brower v. Gateway 2000, Inc. 1998). This article takes note of, but does not delve into, the substantial legal literature on the licensing issue and the problems of the End User License Agreement (EULA). This license affects a user's rights via the doctrine of first sale. The doctrine of first sale, codified into law with the Copyright Act of 1976 (Title 17, Circular 92, Chapter 1, Section 109), permits the sale of legally acquired intellectual property by a first purchaser, provided the first purchaser does not alter it before selling it (Meeker 2006). 
Suffice it to say that the current legal state of affairs is in such flux that differing parts of the United States seem to afford users very different rights, due both to controlling state legislation and the unresolved and conflicting decisions in the various U.S. Circuit Courts (Kelly v. Arriba Soft Corporation 2002/2003; Bridgeport Music, Inc. v. Dimension Films 2005). Until and unless the U.S. Supreme Court decides to act, the geographical location of litigation will in part determine its outcome against certain end users (Lee 2008).

Expanding the Digital Media Taxonomy

Samuelson's (1991) six characteristics of digital media and Lucchi's (2006) addition of intangibility have both been evidence of significant prescience. They accurately predicted the legal and social Pandora's Box that would ensue from digital reproduction. We would here like to propose another characteristic - mixability. When contemporary young people, especially students, engage in multimedia creation, they broadly borrow not only from the work of other artists, but they also select content from different genres and media (e.g., cartoons, animé, manga, background tracks, movie clips, - both originally produced and found) and blend these to create material that reflects the media world as they see it (Aufderheide and Jaszi 2008). However, "ownership" of today's highly variegated media is a vexing concept. Not only are copyrights themselves vigorously defended, but the sheer number of stakeholders is now so large that acquiring the requisite number of permissions can be daunting. In many cases, copyright may be theoretically held by persons whose identities are unknown, or unknowable. One therefore must attempt to obtain rights at one's own peril, and rely on good faith efforts to discover these interested parties. Students in media arts find that, unless they can secure the requisite permissions, which is usually an expensive proposition, they are actively discouraged from borrowing from previously existing work in order to comment upon the media world around them.

Copyright - Different Nations, Different Perspectives

The flouting of copyright in the United States by consumers and students also occurs elsewhere in the world, but often for markedly different reasons. Many countries and cultures around the world do not share the highly specific, capitalistic view of creative work native to the United States.

For example, France actually privileges original creators of most forms of artistic or literary work by giving them the droit moral, which consists of imperishable and inalienable rights related to the quality, provenance and authorship of a work, even after that work has been sold or exploited by another party for economic purposes (The Intellectual Property Code of the Republic of France 2003, Chapter 1). In the United States, such rights are recent, and apply only to visual art, with the notable exception of motion pictures (Rosenblatt 1998). Thus, a culture of remixing is not as prevalent in France, since authors acting on their own may object to the use to which their own creative work has been put.

In many Asian countries, "based on early oral culture, [creators] have not focused [on] personal ownership of ideas" (Mun 2003, p. 3). Thus, we may view unauthorized reproduction of intellectual materials in China, which admittedly is rampant (Report to Congress on China's WTO Compliance 2008), as the result of two intertwined forces. The first is economic, in which net exporters of intellectual property, especially the United States, have sought the maximum 
economic reward for the artistry that they control. The prices set by American companies for their intellectual products, generally film and music, are often high above what Chinese consumers are able or willing to pay (Shenkar 2004). This naturally leads those consumers to seek out alternatives to these high prices on the black market, which has been a standard part of Chinese consumer culture for some time (Mun 2003).

The second force is cultural, in which long standing traditions of the collaborative nature of artistry in China have made such copying a minor taboo at best. Although some Americans regard such unauthorized reproduction as unambiguously wrong, it is not considered particularly egregious by the Chinese. The case is perhaps analogous to the fact that $80 \%$ of Americans regularly exceed the legal speed limit without censure, because doing so does not violate social norms in the U.S. (Harsha and Hedlund 2008/2009).

Japan admits a form of moral rights to its authors that do not expire, although they may be suppressed by mutual contract (Japan Copyright Act 1970, Chapter 3, Article 79). Like China, Japan has also experienced growth in unauthorized media copying (Toi 2002), resulting unfortunately in laws that are in some senses stricter than those in the United States. For instance, many Japan record companies have moved to a copy-protected CD, which prevents its copying in any way by the end user, and be unplayable in a computer's CD-ROM drive (Hu 2002). Moral rights, since they are excepted from economic rights and are inalienable, may in fact suppress creative remixing by student creators, because the author of an underlying element may exercise his "right of integrity," which is "the right to control the act of distorting, mutilating or modifying a work (whether or not such an act damages the authors [sic] honor or prestige" (Copyright Basics for Beginners n.d., Section "Rights of Authors").

Copyright, Education, and the Creative Arts

Young people today, especially students, seem to balk at the above restrictions (Aufderheide, Jaszi and Brown 2007), but they embrace remixing itself. Their very enthusiasm, and the growing acceptance of remixing in American popular culture, shows no signs of letting up. The growth of amateur videographers, photographers and recordists, using programs that

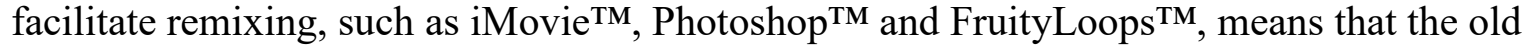
dichotomy between "master practitioners" and "amateurs" is breaking down. This state of affairs has been dubbed "participatory culture" (Lessig 2004). Moreover, it is our view, echoing John Dewey's (Dewey 1916/1966), that education has always been, and should always be about, nourishing the creativity and innovation in the minds of young people for the benefit of citizenship, industry, humanity and the global world community. 
Unfortunately, in their current form, analog copyright regulations do not serve the current and next generation of remixing content creators, and hence their audience, particularly well. This is because virtually any borrowing of media can be construed by enterprising attorneys as infringing (Using Materials from the Internet 2004). According to the U.S. Copyright Office (1976), fair use policies (Title 17, Chapter 1, Section 110 of U.S. Code) seem to allow borrowing of content if the intent is educational in nature, is journalistic commentary, or has a parodic intent. However, such provisions have become less useful for remixers in today's Digital Age (Starr 2005). Fair use guidelines were developed before the advent of digital technologies (e.g., Web 2.0 technologies) and online social sharing networks such as MySpace ${ }^{\mathrm{TM}}$ and Facebook ${ }^{\mathrm{TM}}$, and have been narrowed significantly in scope by subsequent court decisions (cf. Original Appalachian Artworks, Inc. v. Topps Chewing Gum, Inc. 1986).

Student creators today embrace parody and satire, but their use of previously existing intellectual materials is often meant as broader cultural commentary, rather than merely poking fun at earlier work. Rarely is it their point to clandestinely use established work; rather, by using previously existing work as the recognizable stepping-off point for their oeuvre, they situate their own creativity in space and time, while commenting, often elegantly, on the earlier work.

Either a Lender or a Borrower Be: Creative Collaboration in Education and History

Borrowings have an ancient and distinguished provenance. Classical writings formed the bulk of a traditional liberal education a century ago. The use of quotations, characters and entire situations by esteemed authors at that time was commonplace and encouraged (Mullan 2003). Those who read literature were usually very familiar with the mythologies and cultural references that abounded, and these were loaned and borrowed again and again, from the time of Homer through the nineteenth century.

William Shakespeare, for example, developed relatively few completely original plot ideas, characters, or situations for his plays. One of his prominent sources was Raphael Holinshed's Chronicles (as in Holinshed 1554/1965). It is instructive to ask how much less persuasive and powerful Shakespeare's work might have been if he feared suit or censure from Holinshed or his heirs. Yet his plays persist in the culture today - and are heavily borrowed from (e.g. West Side Story 1957; Kiss Me Kate 1953; The Boys from Syracuse 1940) — partly because his particular treatments of borrowed plots and characters have remained so provocative.

But there is another, less artistic reason: Shakespeare has achieved cultural penetration primarily because his work is in the public domain. If it were not, the many films, songs, plays and fiction based on his work, both loosely and faithfully, would cease to exist. Modern dramatists who have learned from, read, and have been inspired by the works of Shakespeare, including many of the greatest from the twentieth century (e.g. T.S. Eliot, Virginia Woolf), have been free to borrow from his work, and it was inconceivable to them, and to their public, that Shakespeare's work, by dint of this treatment, might somehow be injured in the world's estimation.

Contemporary student playwrights, on the other hand, must be very careful in being "inspired by" or "reimagining" plays that have been written after 1923. Although Eugene O’Neill, Arthur Miller and Tennessee Williams, to name three of the most important playwrights that wrote after that date, are all dead, their estates vigorously defend their copyrights against any perceived injury (Literary Legacies 2002). The thoughtful educator might well ask if their reputations would be further enhanced if more contemporary playwrights, especially student 
writers, felt freer to borrow some of their characters, plot structures, and themes, as has been done with Shakespeare and many other writers for more than four hundred years.

Literature is not the only area in which today's student creators must be mindful of burgeoning copyright laws. Because the music and film industries are so profitable, they vociferously defend the copyrights they hold against all comers. The idea is to maximize the profit of the song or film for the complete duration of the copyright. Copyright holders often refuse to grant permission to others to use their materials in a non-standard way, even if it is not clear that such a use is permanently damaging to the original (Darknet.com 2007).

Once again, in the past, such was not the case. Latter composers borrowed from earlier composers, and the expectation was that their audience would recognize the borrowing with delight, as it was a sign of respect for the earlier creator. Brahms, for example, was strongly influenced by Beethoven (James 1972), Beethoven by Mozart (Watson 1937) and so on. As Emerson (1903/1904) said of Shakespeare, "The greatest genius is the most indebted man" (p.189). Similarly, Maurice Baring has observed, "It is only the very rich poets who steal from their fellow poets. The poor do not dare. The contrast would be too sharp between what they have written themselves and what they have borrowed" (p. 248, in Watson 1937).

Obviously, the tenor of educational and cultural life has changed since then; our culture, as well as our laws, seem to demand of artists in any medium that their work be absolutely free of overt, specific influence. However, we believe that in the case of contemporary cultural commentary, earlier work ought to be allowed to be incorporated into later work. The litmus test for its worthiness should be its originality and provocativeness.

Student creators and their audiences evince a marked sophistication about references in popular music, and usually recognize even very short snippets of early songs that have been incorporated into new hits, and know why they have been so assembled. They are aware that such borrowing may represent a playful commentary on the earlier work, whether parodic, as in Luther Campbell's group 2 Live Crew's "Pretty Woman" (Campbell 1989) or honorific Robert Plant's Tall Cool One (1988) (the latter incorporates a short sample from Plant's earlier work with Led Zeppelin). The artists that young people respect and emulate have been doing this kind of borrowing for some time, although only somewhat more recently, paying for the privilege (cf. rapper Biz Markie's difficulties in Grand Upright Music, Ltd v. Warner Bros. Records, Inc. 1991). One common technique used in this borrowing is the practice of sampling a riff, drum pattern or other repeating figure from an earlier, usually popular piece of music, and building an entirely different sort of song from this. "Ain't No Sunshine In This Song," by DMX, (Simmons and Belle 2001) built from Bill Withers' popular 70s hit, "Ain't No Sunshine When She's Gone," (Withers 1971) is an example of this, as is the remake/remix of the Police's "Every Breath You Take," (Sumner 1983) entitled "I'll Be Missing You," by (then monikered) Puff Daddy and Faith Evans, featuring 112 (Combs and Evans 1997). In each case, the earlier song is overtly referred to - in these cases, quite respectfully - but the resultant work is completely transformed. As we indicate above, inexpensive tools now exist which can permit any creative young student of the arts to do this. Unlike these storied artists, however, student creators are frequently unable to pay the thousands of dollars in sample clearance fees that such borrowing frequently entails. 
The Prohibited Recent Past

1923 now stands as a boundary year in copyright. Work created before this date may be borrowed from or appropriated wholesale by students of the arts with complete freedom. Work created after it may not. There is nothing in this date that makes it especially appropriate for this delineation; intellectual property did not suddenly proliferate, or change in quality at that year. It is simply the date at which the ever-lengthening periods of protection afforded to authors begin in the modern era (Bell 2001).

It is also worth noting that the year 1923 is not even a year specifically called for by any legislator, judge, or stakeholder in the process. The uneven legislative road on which copyright has travelled, and been lengthened repeatedly, has simply produced the arbitrary year of 1923 as a watershed, before which the intellectual production of the world is available to any creator, and after which, it is not.

Of course, it is possible to argue that a creator might or should refrain from all overt reference to prior existing works, in order to create work of the greatest ingenuity. But attempts to strangle even off-hand, casual or sidelong references to creative or intellectual milestones are usually efforts to privilege their status as economic engines, rather than creative cynosures. The Sonny Bono Copyright Act (1998), for example, was passed at the express behest of the Walt Disney Company (Sprigman 2002), because their much-beloved (and profitable) character, Mickey Mouse, was in danger of falling into the public domain. The act extended by twenty years the protection accorded the fictional rodent, as well as preserving the income stream of the innumerable DVDs, tapes, and films featuring this character. The Walt Disney Company may legitimately wish to continue creating animated cinematic narratives featuring Mickey Mouse and others of his anthropomorphic ilk. Many of these works have been praised for their artistic quality. But the Walt Disney Company is a corporation, and it acts in the best interests of the stockholders of that corporation - above any other consideration.

It is also true that once Mickey Mouse and other favorite childhood characters fall into the public domain, savage, even obscene caricatures of them might proliferate for a time. Nevertheless, the main casualty of the suppression of such unflattering portraiture is the First Amendment's (Bill of Rights 1789) broad ambit of protection. Surely, a vigorous, unfettered discussion of ideas, whether newly hewn, or framed in the metaphor of the remixer's art (Lessig 2004), is a bargain for all. We believe that such a bargain means that the originators of popular fictional creations, whether in motion pictures, music or in literature, will find that their work is discussed and appropriately credited (and therefore, purchased) far more than what would otherwise occur, because such a discussion can occur in a free and transformative creative environment. The stumbling block is copyright law, which, as it is currently codified, instills a chilling effect on this theoretical - yet we believe infinitely preferable - participatory commentary.

Conclusion

New, legally acceptable avenues for remixed content, both for creators and consumers, have yet to be found. We believe they will be found when our culture re-examines fair use, particularly in the light of the non-commercial intent of many of today's student creators and remixers. We believe that young content remixers today are engaged in a novel form of cultural commentary. We believe that such commentary should be permitted wider latitude in terms of 
the extent of its borrowing, especially for educational and non-commercial enterprises.

As Baron (1997) has asked, "What rights are right, what obligations are necessary, what compromises are realistic, and what kinds of procedures may be used to facilitate exercising these rights and meeting these obligations" (p. 235). Obviously, there are numerous notable attempts at reform of copyright. Some of these involve the liberalization of copyright. Since the U.S. has traditionally led the way in this area, legislative efforts there are worth reviewing. In the $110^{\text {th }}$ Congress, Rep. Rick Boucher (D -VA) introduced a bill he called the Freedom and Innovation Revitalizing U.S. Entrepreneurship Act of 2007 (the FAIR USE Act of 2007). This bill would provide some clarifications of fair use and also would not penalize those who seek to utilize fair use by bypassing technological restrictions built into a piece of media, especially those that inhibit copying.

We also believe that the non-commercial remixing and repurposing of aspects of popular culture is a boon for that culture. We are joined in this belief by Lawrence Lessig and his partners, who created the Creative Commons website (creativecommons.org). Lessig's purpose was to respect copyright, but to permit creators to license some or all of their intellectual property specifically for the reuse, repurposing and even modification by others. We have introduced our own students to this website, for the expressed purpose of permitting them maximum creative freedom in the manipulation of audio and video, with the goal of creating something entirely new out of pre-existing pieces.

The two initiatives above are examples of the continued effort to revise or supplement existing copyright law in the U.S., in ways that will support both the sharing and producing of creative work using the latest web-based networks and digital technologies. What is next needed is to encourage such initiatives in other nations. The ideal forum for such conversations is the Berne Convention. The Berne Convention (1886) was convened at the behest of celebrated French author Victor Hugo, who saw an international need to protect the books and papers of authors, and, as time went on, a plethora of other intellectual property. However, as we have shown above, each nation has folkways and customs regarding copyright that are at least partially unique to itself. Nevertheless, in the contemporary world, most nations welcome and even clamor for exposure to the creative and intellectual property of other nations. For them to make the best use of these opportunities, they, and the United States especially, need to come to a rapprochement regarding certain issues that divide them, such as the droit moral and draconian notions of fair use.

We realize that care must be taken in the appropriation and manipulation of the intellectual property of others. No one should be able to claim authorship of another's material as their own. Remixing and other re-purposing of extant media must always prominently reveal the original authorship of the component parts. If there is a profit motive to the creation of new media out of the old, all component creators must share in this income stream. In many cases however, the intent of remixed media is educational, commentative, and primarily transformative, thus purposively non-commercial. As Dewey (1916) opined, "the innovator who achieves anything enduring, whose work is more than a passing sensation, utilizes classic methods [we add here 'existing works'] more than may appear to himself or to his critics. He devotes them to new uses, and in so far transforms them" (p. 150). Such new and transformative uses of copyrighted material should be more than permitted; they should be encouraged. Otherwise, the richness and variegation of our culture is at risk. 


\section{References}

Aufderheide, P. and P. Jaszi. 2008. Recut, reframe, recycle: Quoting copyrighted material in user-generated video. Center for Social Media, School of Communication American University Report. Washington, DC. http://www.centerforsocialmedia.org/resources/publications/recut_reframe_recycle (accessed June 30, 2008).

Aufderheide, P., P. Jaszi, and N. B. Brown. 2007. The good, the bad, and the confusing: usergenerated video creators on copyright. Center for Social Media, School of Communication American University Report. Washington, DC.

http://www.centerforsocialmedia.org/files/pdf/good_bad_confusing.pdf (accessed March 24, 2008).

Baron, R.A. 1997. Editor's introduction, summary and analysis. Visual Resources, 12: 233-259.

Bell, T. W. 2001. Escape from copyright: market success vs. statutory failure in the protection of expressive works. The University of Cincinnati Law Review 69, 741.

Bill of Rights. 1789. The National Archives and Records Administration. College Park, MD. http://www.archives.gov/exhibits/charters/charters.html (accessed July 30, 2008)

Blake, J. 1982, July 1. Get set for a whirl with new mini-discs! The Sun. http://bp0.blogger.com/_AzT5pruwnbg/SAanRZrjPHI/AAAAAAAAD4M/NAIircohlXg/s1600h/Compact+82.jpg (accessed July 30, 2008).

Boehlert, E. 2000, August 8. Four little words. Salon. http://archive.salon.com/ent/music/feature/2000/08/28/work_for_hire/index.html (accessed July 30, 2008).

Boorstin, E. S. 2004. Music sales in the age of file sharing. Unpublished A.B. Thesis, Princeton University, Princeton, N.J.

Bridgeport Music, Inc. v. Dimension Films, 410 F.3d 792 (6th Cir. 2005). http://fsnews.findlaw.com/cases/6th/04a0297p.html (accessed July 31, 2008).

Brower v. Gateway 2000, Inc. 676 N.Y.S.2d 569 (New York Supreme Ct. App. Div. [Aug.] 1998). http://www.internetlibrary.com/pdf/Brower-Gateway-2000.pdf (accessed July 31, 2008).

Campbell, L. 1989. Pretty Woman. On As Clean as they Wanna Be [LP]. Miami, FL: Luke Records.

Combs, S., and Faith Evans. 1997. I'll Be Missing You[ CD Single]. On No Way Out, New York. Bad Boy, distributed by Atlantic. 
Copyrights basics for beginners: What is copyright? N.D. Copyright Research and Information Center (CRIC) http://www.cric.or.jp/cric_e/beginner/beginner.html (accessed April 29, 2009).

Cortada, J. 1996. Commercial applications of the digital computer in American corporations, 1945-1995. IEEE Annals of the History of Computing, 18(2). http://www.informatik.unitrier.de/ ley/db/journals/annals/annals18.html (accessed July 24, 2008).

Darknet.com. 2007. [Website]. http://www.darknet.com/2005/07/when_the_studio.html (accessed July 30, 2008).

Creative Commons. [Website]. http://creativecommons.org/

Desmonde, W. H., and Berkling, K. J. 1966. The Zuse Z3. german predecessor of the mark I. [Monograph]. http://www.zib.de/zuse/English_Version/index.html (accessed April 30, 2009).

Dewey, J. 1916/1966. Democracy and education. New York: Free Press.

Electronic Performance Support Systems (EPSS): Designer's Gallery Consumer Software. http://www.pcd-innovations.com/infosite/packaged.htm (accessed July 24, 2008).

Emerson, R. W. 1903/1904. Representative men, seven lectuires: Shakspeare; or, the Poet, 4(5). In The complete works of Ralph Waldo Emerson (Centenary Edition). Boston and New York: Houghton Mifflin and Company.

Gizelt, J. 1997, August 21. Digital vs. analog part II. Film Score Daily. http://www.filmscoremonthly.com/articles/1997/21_Aug---Digital_vs.asp (accessed July 24, 2008).

Gordon, W. J., and R. Watt (Eds.). 2003. The economics of copyright. Northampton, MA: Edward Elgar Publishing.

Grand Upright Music, Ltd v. Warner Bros. Records, Inc., 780 F.Supp. 182 (S.D.N.Y. 1991). http://cip.law.ucla.edu/cases/case_grandwarner.html (accessed July 31, 2008).

Harsha B., and Hedlund, J. 2008/2009. Traffic safety culture: What can we do to change it? Traffic Safety Center Newsletter, 5(1).

http://www.tsc.berkeley.edu/newsletter/winter2008/howchange.pdf (accessed April 28, 2009).

Holinshed, R. 1965. Holinshed's Chronicles England, Scotland, and Ireland [original print 1577]. (Ed.Vernon F. Snow). New York: AMS.

Hu, J. April 1, 2002. Warner Japan adding CD copy protection. CNET News. http://news.cnet.com/Warner-Japan-adding-CD-copy-protection/2100-1023_3-872475.html (accessed April 29, 2009). 
Hurwitz, D. S. 2005. A proposal in hindsight: Restoring copyright's delicate balance by reworking 17 U.S.C. § 1201. UCLA Journal of Law and Technology, 9(2).

http://www.lawtechjournal.com/articles/2005/01_050528_hurwitz.pdf (accessed July 24, 2008).

Information behaviour of the researcher of the future. 2008. The University College London (UCL) CIBER Group. http://www.bl.uk/news/pdf/googlegen.pdf (accessed June 30, 2008).

Inventor of the Week. 2007. Steve Jobs and Steve Wozniak: The personal computer. Massachusetts Institute of Technology: School of Engineering. http://web.mit.edu/invent/iow/apple.html (accessed July 29, 2008).

James. B. 1972. Brahms: A Critical Study. London: Dent.

Japan Copyright Act No. 48. 1970. [English translation effective July 1, 2007]. Chapter 3, Article 79. http://www.cas.go.jp/jp/seisaku/hourei/data/CA.pdf (accessed April 28, 2009).

Kant, I. 1785. The injustice of counterfeiting books (S. Palmquist trans). http://www.hkbu.edu.hk/ ppp/fne/essay3.html (accessed July 23, 2008).

Kelly v. Arriba Soft Corp., 77 F.Supp.2d 1116 (C.D. Cal. 1999), aff'd in part, 336 F.3d 811 (9th Cir. 2003).

http://homepages.law.asu.edu/ dkarjala/cyberlaw/KelllyvArriba(9C2003).htm(accessed July 31, 2008).

Kempf, K. 1961. U.S. Army ordnance: electronic computers within the Ordnance Corps.

Computer History Museum [Website]. http://www.computerhistory.org/exhibits/ (accessed July 24, 2008).

Kennedy, J. 2008. Revolution, renovation, responsibility. IFPI Digital Music Report. IFPI, UK. http://www.ifpi.org/content/library/DMR2008.pdf (accessed July 24, 2008).

Kiss Me Kate [Motion Picture]. 1953. United States: Metro-Goldwyn-Mayer.

Langenderfer, J. and D.L. Cook. 2001. Copyright policies and issues raised by A\&M Records v. Napster: "The shot heard "round the world" or "not with a bang but a whimper?" Journal of Public Policy \& Marketing 20, (2): 280-288.

Lee, J.A.N. 1994. Charles Babbage. http://ei.cs.vt.edu/ history/Babbage.2.html (accessed July $24,2008)$.

Lee, S. 1995. Independent record companies and conflicting models of industrial practice. The Journal of Media Economics, 8(4), 47-61.

Lee, T.B. 2008, May 23. Court smacks Autodesk, affirms right to sell used software. Ars Technica. http://arstechnica.com/news.ars/post/20080523-court-smacks-autodesk-affirms-rightto-sell-used-software.html (accessed July 24, 2008). 
Lessig, L. 2004. Free culture: How big media uses technology and law to lock down culture and control creativity. New York: The Penguin Press.

Levy, S. 2001. Hackers: Heroes of the computer revolution. New York: Penguin Books.

Literary Legacies: Executors, Duty, the Law-- and a Proposal. 2002, November. The Complete Review Quarterly, 3(4). http://www.complete-review.com/quarterly/vol3/issue4/litlegs.htm (accessed July 29, 2008).

Lucchi, N. 2006. Digital media and Intellectual property: Management of rights and consumer protection in a comparative analysis. New York: Springer Verlag.

Meeker, H. 2006, May 16. Only in America? Copyright law key to global free software model. [White paper]. ECT News Network. Linux Insider. http://www.linuxinsider.com/story/50421.html (accessed July 24, 2008).

Mitrano, T. 2007. Copyright primer for Cornell University digital education program. Cornell, NY: Cornell University Office of Information Technologies. http://www.cit.cornell.edu/policy/copyright/primer.html (accessed July 23, 2008).

Mullan, J. 2003, January 18. Ancient borrowings. The Guardian. http://www.guardian.co.uk/books/2003/jan/18/featuresreviews.guardianreview33 (accessed July $31,2008)$.

Mun, S. 2003. A new approach to U.S. copyright policy against piracy in China. Paper presented at the annual meeting of the International Communication Association, San Diego, CA. PDF>. 2009-02-06 from http://www.allacademic.com/meta/p111851_index.html (accessed April 28, 2009).

Nakano, H., and M. Nakamura. 1997. The disc designers. Sound on Sound 12(5). http://www.soundonsound.com/sos/1997_articles/mar97/sonymen.html?print=yes (accessed June $30,2008)$.

Nyiri, J. 2004. The effects of piracy in a university setting. ACM Crossroads, Ethics and Computer Science, 10(3). http://www.acm.org/crossroads/xrds10-3/piracy.html (accessed July $23,2008)$.

Oberholzer, F. and C. Strumpf. 2004. The effect of file sharing on record sales: An empirical analysis. Journal of Political Economy, 115(1).

http://www.journals.uchicago.edu/JPE/journal/issues/v115n1/31618/brief/31618.abstract.html?er From $=5354457547488900819$ Guest (accessed July 23, 2008).

Original Appalachian Artworks, Inc. v. Topps Chewing Gum, Inc., 642 F. Supp. 1031 (N.D. Ga. 1986). http://fairuse.stanford.edu/Copyright_and_Fair_Use_Overview/chapter9/9-b.html\#5 (accessed July 31, 2008). 
Palmer, J.F., and C.B. Ward 1926. The Band Played On. On Guy Lombardo and His Orchestra (78 record, Decca catalog number 3675 [reissued as number 25451]). New York, Decca.

Peitz, M., and P. Waelbroeck. 2004. The effect of Internet piracy on CD sales: Cross-section evidence. Unpublished scholarly paper. CESifo Working Paper Series No. 1122. National Bureau of Economic Research (NBER). http://www.serci.org/2004/waelbroeck.pdf (accessed July 23, 2008).

Pew Internet and American Life Project. 2005. Teen content creators and consumers [Report]. Washington, DC. http://www.pewinternet.org/PPF/r/166/report_display.asp (accessed March 24, 2008).

Plant, R. 1988. Tall Cool One. On Now and Zen (LP). Los Angeles: Es Paranza 90863.

Raymond, E.S. 2000. A brief history of hackerdom. http://www.catb.org/ esr/writings/cathedral-bazaar/hacker-history/index.html (accessed July 23, 2008).

Reimer, J. 2005. A history of the GUI. Ars Technica. http://arstechnica.com/articles/paedia/gui.ars (accessed July 29, 2008).

Report to Congress on China's WTO Compliance. 2008.

http://www.ustr.gov/assets/Document_Library/Reports_Publications/2008/asset_upload_file192_ 15258.pdf (accessed April 28, 2009).

Rojas, R. 1999. Konrad Zuse (1910-1995). [Monograph].

http://www.zib.de/zuse/English_Version/index.html (accessed April 30, 2009).

Rosenblatt, B. 1998. Moral rights basics.

http://cyber.law.harvard.edu/property/library/moralprimer.html (accessed April 28, 2009).

Samuelson, P. 1991. Digital media and the law. Journal of Communications of the ACM, 34(10). http://mail.tku.edu.tw/117520/Samuelson.htm (accessed March 24, 2008).

Simmons, E., and R. Belle. 2001. No Sunshine. [CD Single]. Uptown/Universal.

Shenkar, O. 2004. The Chinese century: The rising Chinese economy and its impact on the global economy, the balance of power, and your job. Philadelphia, PA: Wharton School Publishing.

Sprigman, C. 2002, March 5. The mouse that ate the public domain: Disney, the Copyright Term Extension Act, and Eldred V. Ashcroft. FindLaw. http://writ.news.findlaw.com/commentary/20020305_sprigman.html (accessed July 29, 2008).

Stapleton, L. L and Walker, J. 2002. E- copyright law handbook. New York: Aspen Publishers. 
Starr, L. 2005. Applying fair use to new technologies: Part 4 of an Education World series on copyright and fair use. Education World. http://www.educationworld.com/a_curr/curr280d.shtml (accessed April 15, 2008).

Step-Saver Data Sys., Inc. v. Wyse Tech., 939 F.2d 91 (3d Cir. 1991).

http://cyber.law.harvard.edu/metaschool/fisher/contract/cases/step.htm (accessed July 30, 2008).

Strauss, N. 2003, September 14. File-sharing battle leaves musicians caught in middle. The New York Times.

http://www.nytimes.com/2003/09/14/technology/14MUSI.html?ex=1378872000\&en=2832300e 467debbe\&ei=5007\&partner=USERLAND (accessed July 30, 2008).

Sumner, G. 1983. Every Breath You Take [Recorded by The Police]. On Synchronicity [LP]. New York: A\&M.

Talab, R. S. 2002. Napster, distributed peer sharing, and its chronology: "You say you want a revolution?" TechTrends 46(3): 3-6.

Timeline of Computer History. [Website]. http://www.computerhistory.org/timeline/?year=1990 (accessed July 30, 2008).

Toi, S. Feb. 21, 2002. Online music trade riles labels: Record industry orchestrates legal action, copy-proofing. The JapanTimes [Online]. http://search.japantimes.co.jp/cgibin/nn20020221b9.html

Tuck, M. 2001, August 13. The real history of the GUI. Sitepoint. http://www.sitepoint.com/article/real-history-gui (accessed July 29, 2008).

The Avalon Project. n.d. The Statute of Anne; April 10, 1710. Yale Law School, Lillian Goldman Law Library in Memory of Sol Goldman, New Haven, CT. http://www.yale.edu/lawweb/avalon/eurodocs/anne_1710.htm (accessed July 23, 2008).

The Boys from Syracuse [Motion Picture]. 1940. United States: Universal Pictures.

The Berne Convention Act. 1886. Copyright Law of the United States of America, Title 17, Circular 92 . Washington, DC: U.S. Copyright Office.

http://www.copyright.gov/title17/92appii.html

The Freedom and Innovation Revitalizing U.S. Entrepreneurship Act (FAIR USE Act 2007). Washington, DC: The Office of Congressman Rich Boucher. http://www.boucher.house.gov/index.php?option=com_content\&task=view\&id=1011\&Itemid=7 5 (accessed April 28, 2009).

The Intellectual Property Code of the Republic of France. 2003. The Republic of France. http://www.legifrance.gouv.fr/html/codes_traduits/cpialtext.htm (accessed April 28, 2009). 
ThePiratebay.org. [Website]. http://thepiratebay.org/

UCLA Online Institute for Cyberspace Law and Policy. 2001. A\&M Records v. Napster: MP3 file sharing disputes continue in the aftermath of recent court rulings. The Cyberspace Law \& Policy Institute Archives. University of California, Los Angeles. http://www.gseis.ucla.edu/iclp/napster.htm (accessed March 8, 2008).

U.S. Constitution. 1789. The United States Constitution. Article I, Section 8, Clause 8. Washington, DC: U.S. House Government. http://www.house.gov/house/Constitution/Constitution.html (accessed March 24, 2008).

U.S. Code. 1976. The United States Copyright Act of 1976. Washington, DC: U.S. Copyright Office. http://www.copyright.gov/title17/92chap1.html (accessed March 10, 2008).

U.S. Code. 1998. The Sonny Bono Copyright Extension Act. Title 17, Chapter 3. Washington, DC: U.S. Copyright Office. http://www.copyright.gov/title17/92chap3.html (accessed March 10, 2008).

U.S. Code. 1998. The Digital Millennium Copyright Act (DMCA). Washington, DC: U.S. Copyright Office. http://www.copyright.gov/reports/studies/dmca/dmca_study.html (accessed March 9, 2008).

U.S. Code. 1992. The Audio Home Recording Act of 1992. Title 17, Chapter 10. Washington, DC: U.S. Copyright Office. http://www.copyright.gov/title17/92chap10.html (accessed March 10, 2008).

Using Materials from the Internet. 2004. The University of Texas System, Intellectual Property Use of Net [Website]. http://www.utsystem.edu/ogc/intellectualproperty/useofnet.htm (accessed, July 30, 2008).

van Hooff, R. 2007. Independent record companies in the digital era on threats and opportunities in a changing recording industry. Master's thesis, Erasmus University. Rotterdam. https://ep.eur.nl/scripties/bitstream/2105/4296/1/Ruben+van+Hooff+thesis.pdf (accessed March $10,2008)$.

Watson, J. A. 1937. Beethoven's debt to Mozart. Music \& Letters, 18(3), 248-258.

West Side Story [Motion Picture]. 1961. United States: Mirisch Corporation.

Weyhrich, S. 2001. Apple II history.

http://inventors.about.com/gi/dynamic/offsite.htm?zi=1/XJ\&sdn=inventors\&cdn=money\&tm=37 $\& \mathrm{f}=00 \& \mathrm{su}=\mathrm{p} 664.3 .336 . \mathrm{ip} \_\& \mathrm{tt}=2 \& \mathrm{bt}=1 \& \mathrm{bts}=0 \& \mathrm{zu}=\mathrm{http} \% 3 \mathrm{~A} /$ /apple2history.org/history/ah01.ht $\mathrm{ml}$ (accessed July 29, 2008). 
Withers, B. 1971. Ain't No Sunshine When She's Gone. On Just As I Am (LP). New York: Columbia.

Zeropaid.com. [Website]. http://www.zeropaid.com/ (accessed July 29, 2008). 